\title{
PULMONARY COMPLICATIONS AND CARDIOPULMONARY BYPASS: A CLINICAL STUDY IN ADULTS
}

\author{
K.W. Turnbull, B.A.SC., M.D., ${ }^{*}$ R.T. Miyagishima, B.A., M.D., $\dagger$ AND. \\ A.N. GEREIN, M.D. $\dagger$ \\ Presented at Canadian Anaesthetists' Society Annual Meeting, Vancouver, June, 1973.
}

THE USE of cardiopulmonary bypass and of the pump oxygenator has increased as newer surgical techniques have been developed. Pulmonary complications, particularly those of the left lower lobe, have remained frequent following bypass $^{1}$ despite the decrease in the post-perfusion syndrome or "pump lung" attributed to improved venting of the left ventricle and atrium ${ }^{2}$ and/or the use of low molecular weight dextran. ${ }^{3}$ This study is an attempt to present the nature and frequency of these complications and to correlate these changes with pulmonary function during the first post-operative week. Pulmonary function was assessed using alveolo-arterial oxygen gradients $\left(\mathrm{A}-\mathrm{aDO} \mathrm{D}_{2}\right)$, arterio-alveolar carbon dioxide gradients $\left(\mathrm{a}-\mathrm{ADCO}_{2}\right)$, steady-state diffusing capacity for carbon monoxide $\left(D_{\text {coss }}\right)$, and physiological dead space-tidal volume ratios $\left(V_{D} / V_{T}\right)$ in association with the roentgenologic changes.

\section{Materials and Methods}

Nineteen patients were studied. They were clinically free of chest disease or overt uncontrolled congestive heart failure with the exception of one (case No. 11). Seventeen had coronary artery bypass grafts for refractory or intractable angina pectoris; one (No. 11) had mitral and aortic valve replacement because of refractory congestive heart failure and the remaining one (No. 15) had an aortic valve replacement. The clinical details are shown in Table I. All patients had cardiopulmonary bypass using a Sarns roller pump with the Bentley "Temptrol" reservoir and bubble oxygenator. Prime consisted of three units of heparinized homologous blood (3-5 days old) mixed with 1.5 to 2.0 litres of two-thirds 5 per cent $\mathrm{G} / \mathrm{W}$ with one-third $\mathrm{N} / \mathrm{S}$. Blood flow was maintained at 2.2 liters $/ \mathrm{M}^{2}$ minute at $35^{\circ} \mathrm{C}$. with a minimum perfusion pressure of $60 \mathrm{~mm} \mathrm{Hg}$ after adequate venting of left atrium and ventricle. During bypass the lungs were kept statically inflated with a mixture of nitrous oxide and oxygen 50:50 at 10 $\mathrm{cm} \mathrm{H}_{2} \mathrm{O}$ pressure and humidified using an ultrasonic nebulizer. Three "sighs" were administered during most periods of bypass and again after the patient had come off bypass.

The clinical and operative records were reviewed for factors which might have

- From Department of Anaesthesiology, Vancouver General Hospital, and Faculty of Medicine, University of British Columbia.

†Department of Surgery, St. Paul's Hospital, and the Faculty of Medicine, University of British Columbia, Vancouver, B.C.

Canad. Anaesth. Soc. J., vol. 21, no. 2, March 1974 
contributed to the development of post-operative complications. ${ }^{4}$ These factors included age, pre-operative chest disease, duration of bypass, duration of operation and of anaesthesia, hypotension, fibrillation and variations in pre-operative and post-operative roentgenograms. All pre-operative roentgenograms were normal with the exception of left ventricular hypertrophy in patient No. 11.

All patients were seen 24 hours pre-operative, 60 minutes prior to induction of anaesthesia and then at one, three and seven days post-operatively. The $D_{\text {coss }}$ was measured using the steady-state method as proposed by Filley, MacIntosh and Wright ${ }^{5}$ using $0.125-0.150$ per cent $\mathrm{CO}$ in air from a Collins 9-litre recording spirometer in series with an 87.5-litre storage bag. Breathing of this mixture continued for three minutes. When the end-tidal carbon dioxide concentration had been constant for 10 to 15 minutes blood samples were taken from the radial or femoral artery with the patient supine. The patients breathed room air for 10 to 15 minutes, the samples were taken, and the sequence was repeated using 100 per cent oxygen. In the operating room arterial samples were collected from brachial artery catheters one hour after pre-medication with a narcotic and belladonna, while the patients were awake and supine. The post-operative sequences were similar. Random arterial punctures were made on the second post-operative day for arterial oxygen tensions.

Collection of end-expiratory and mixed expiratory gas samples was done with a Rahn-Otis End-Tidal Sampler and a baffled (expiratory) 15-litre rubber bag. Continuous measurements of the end-expiratory and the mixed expired gases were obtained using a Beckman $\mathrm{CO}_{2}$ analyzer and a Beckman oxygen analyzer connected in series. A Beckman micro-catheter sample pump moved the $200 \mathrm{cc}$ sample through a constant length of plastic tubing from the end-tidal sampler or expiratory bag through the meters. The meters were pre-calibrated with gases analyzed by the Scholander method. Tidal volumes were measured preoperatively with a Collins 9-litre spirometer while a Wright's respirometer, precalibrated with the Collins spirometer, was used in the operating room.

Blood samples were taken in heparinized glass syringes, immediately iced and placed in a refrigerator at $4^{\circ} \mathrm{C}$. Analysis was done within 30 minutes. Blood gas tensions and $\mathrm{pH}$ were measured with a Radiometer $\mathrm{pH} /$ Blood Gas Monitor and Micro-electrode Unit at $37^{\circ} \mathrm{C}$. Calibration of this apparatus was done before and after each set of determinations.

The mean-end-tidal oxygen and carbon dioxide concentrations of the respiratory cycle corresponding to the blood sampling period were assumed to equal the alveolar oxygen and alveolar carbon dioxide concentrations. ${ }^{6}$ These values were used to calculate $\mathrm{A}-\mathrm{aDO}_{2}$ and $\mathrm{a}-\mathrm{ADCO}_{2}$ after allowance was made for ambient barometric and water vapour pressures. $V_{\mathrm{D}} / \mathrm{V}_{\mathrm{T}}$ ratios were based on the Riley modification of the Bohr equation ${ }^{7}$ substituting arterial carbon dioxide for the ideal alveolar $\mathrm{PCO}_{2}$. The statistical evaluations were based on the paired two-tailed t-test ("Student t-test") and the method of least squares. The roentgenograms were evaluated and classified as unchanged ("none"), "patchy" - if spotty and/or scattered areas of atelectasis were present and "collapsed" if a lobe was involved with consolidation and/or atelectasis was present as shown in Table I. The patients were extubated within four hours after operation and only one (No. 19) required controlled ventilation post-operatively for 12 hours. 
CANADIAN ANAESTHETISTS' SOCIETY JOURNAL

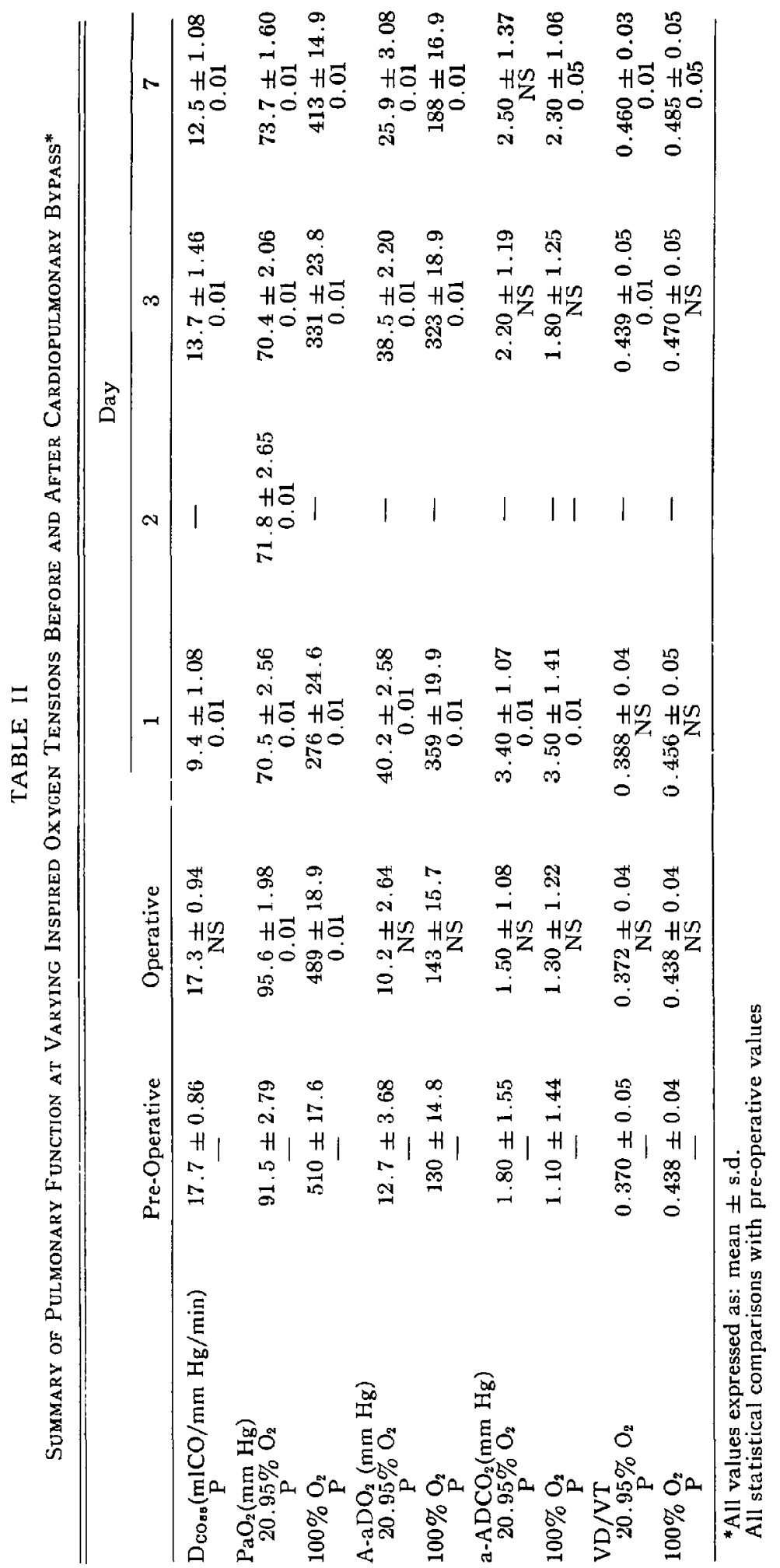




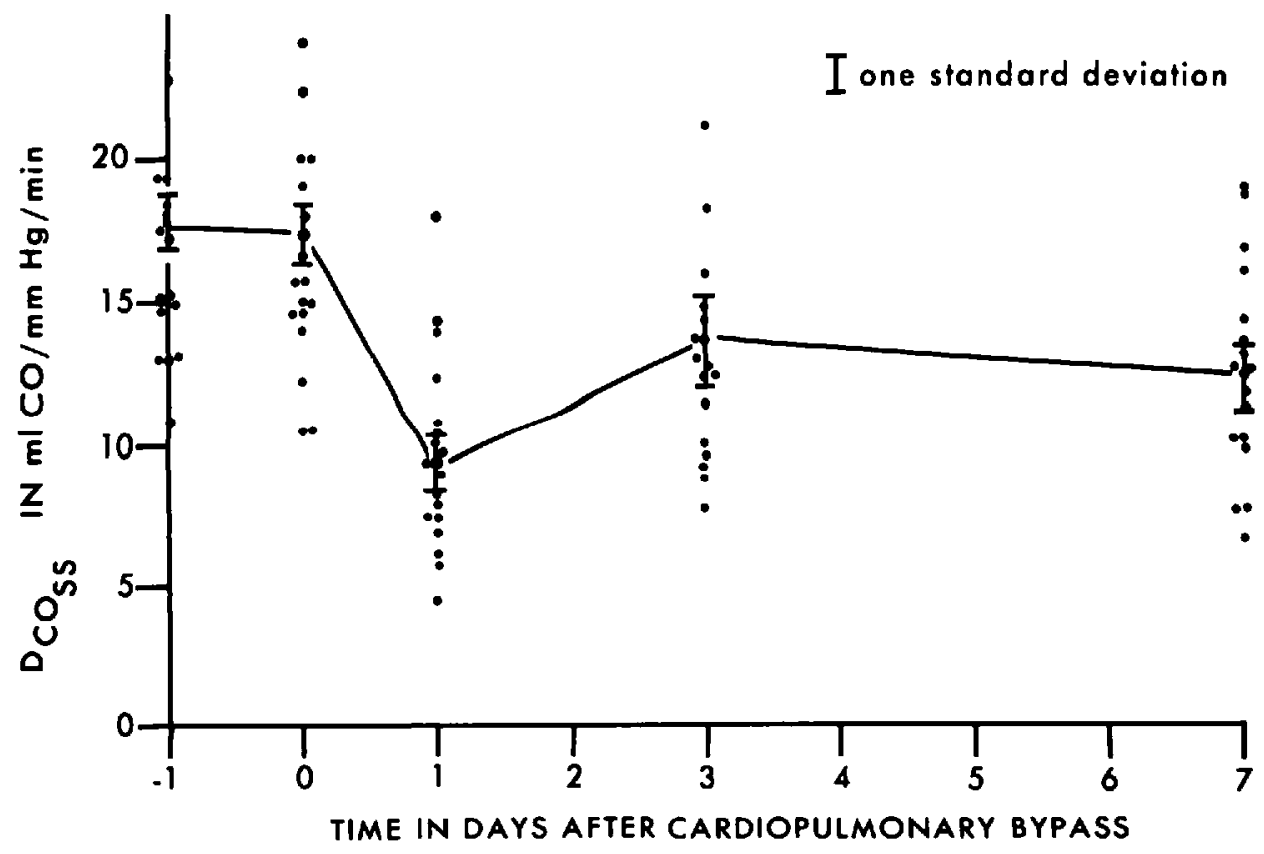

Figure 1. Variation in steady-state diffusion capacity for $\mathrm{CO}$ with time before and after cardiopulmonary bypass.

\section{Results}

Analysis of the results shown in Tables I and II reveals highly significant changes in roentgenograms and pulmonary function starting on the first postoperative day. These persist until the third post-operative day with some improvement by the seventh post-operative day. The $D_{\text {Coss }}$ is markedly decreased post-operatively and slow to improve as shown in Figure 1 . The $\mathrm{PaO}_{2}$ reflects the duration of bypass and roentgenogram changes. Patients were on room air and values are related to gradual improvement with re-expansion of atelectasis or resolution of consolidation. This is shown by the plateau of $70.5 \mathrm{~mm} \mathrm{Hg}$ in Figure 2. Note that the $\mathrm{PaO}_{2}$ by the second post-operative day was $71.5 \mathrm{~mm} \mathrm{Hg}$. Patients with "patchy" changes (Figure 3) had few clinical findings, e.g. scattered crepitations. Only those patients with "collapse" (as shown in Figures 4 and 5) had shifted diaphragms and bronchial breathing. $\mathrm{A}-\mathrm{aDO}_{2}$ gradient changes with patients on 100 per cent oxygen were highly significant and provided the greatest variation as shown in Figure 6. Changes in a-ADCO${ }_{2}$ gradient were highly significant on the first post-operative day but were not significantly changed after that, as shown in Figure $7 . V_{\mathrm{D}} / \mathrm{V}_{\mathrm{T}}$ changes were highly significant from the third to seventh post-operative days as shown in Figure 8. Premedication had no adverse effect on pulmonary function. ${ }^{8}$ The duration of bypass was the only clinical factor significantly related to the $\mathrm{PaO}_{2} 24$ hours postoperatively, as shown in Figure 9. 


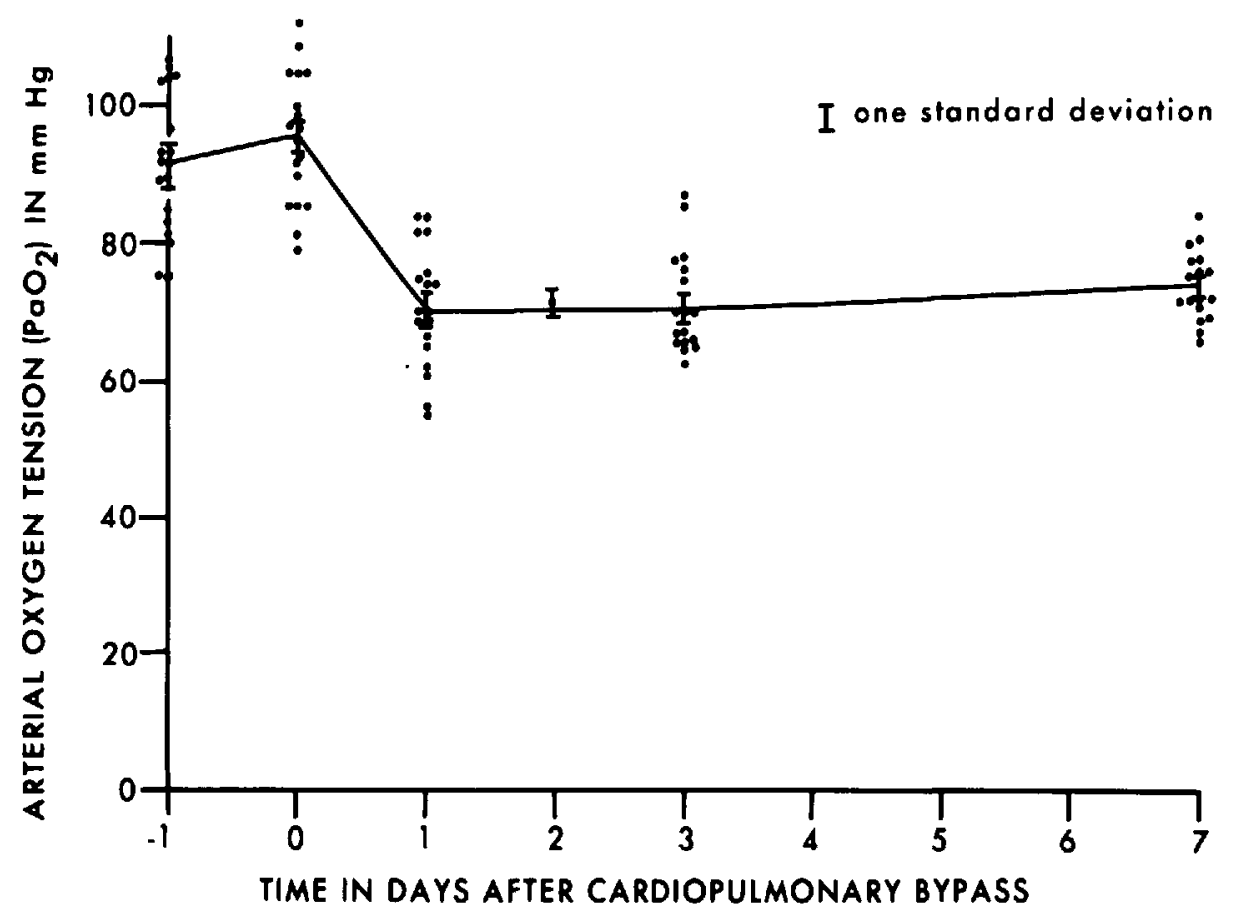

Figure 2. Variation in arterial oxygen tensions $\left(\mathrm{PaO}_{2}\right)$ with time before and after cardiopulmonary bypass (subjects on room air, 20.95\% $\mathrm{O}_{2}$ ).

\section{Discussion}

This study shows arterial oxygen tensions may be at hypoxic levels 24 hours or more after cardiopulmonary bypass, if the patient is breathing room air. A 22 per cent decrease in $\mathrm{PaO}_{2}$ at that time is due to physiological shunting in atelectatic or collapsed lung. ${ }^{9}$ Ventilation-perfusion $(\dot{V} / \dot{Q})$ abnormalities become significant three to seven days after operation. These conclusions are supported by the combination of a decreased $\mathrm{D}_{\mathrm{COss}}$, and increased $\mathrm{A}-\mathrm{aDO}_{2}$ and delay in significant $\mathrm{V}_{\mathrm{D}} / \mathrm{V}_{\mathrm{T}}$ changes until collapsed or atelectatic lung areas are resolving. The decreased $\mathrm{D}_{\text {coss }}$ could be due to shunts, $\dot{\mathrm{V}} / \dot{\mathrm{Q}}$ increases," lung volume decreases or diffusion blocks. ${ }^{10,11}$ The increased $A-\mathrm{aDO}_{2}$ and $\mathrm{V}_{\mathrm{D}} / \mathrm{V}_{\mathrm{T}}$ changes support the existence of shunts and tend to eliminate $\dot{V} / Q$ increases or decreases in cardiac output. ${ }^{12}$

The techniques used in this study showed a- $\mathrm{ADCO}_{2}$ gradient increases 24 hours post-operatively followed by smaller changes, but there were such large variations that no significant statistical differences could be demonstrated. Although the large $\mathrm{A}-\mathrm{aDO}{ }_{2}$ gradient on 100 per cent oxygen could be due to $\dot{\mathrm{V}} / \dot{\mathrm{Q}}$ increases, the $V_{D} / V_{T}$ changes were minimal until the third to seventh day suggesting that there was very little change in the ventilation itself. Likely the technique used (Rahn-Otis End Tidal Sampler) is limited when assessing a- $\mathrm{ADCO}_{2}$ in patients with significant pulmonary dysfunction after operations on 


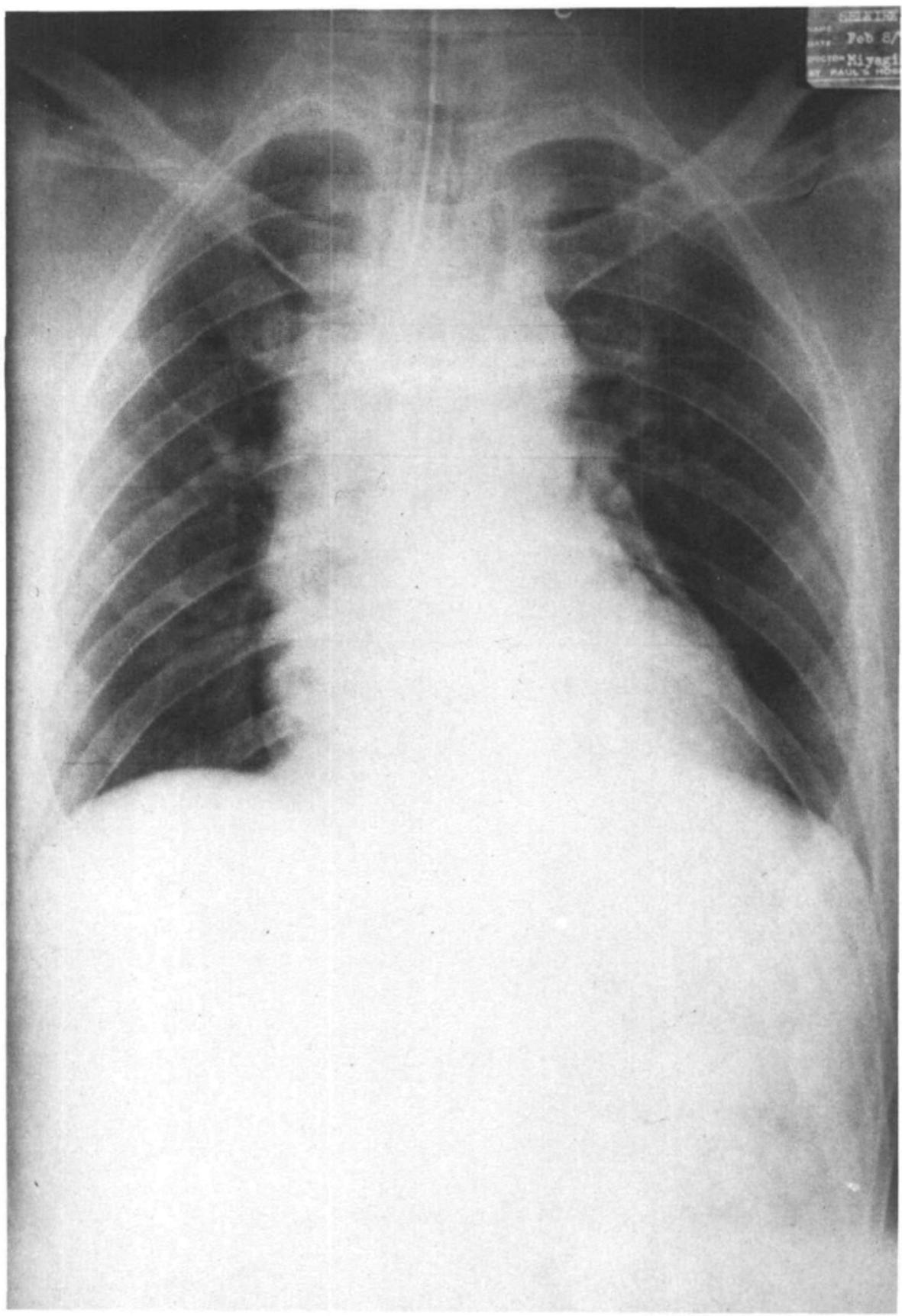

Figure 3. Radiograph showing "patchy" atelectatic changes.

the heart. Although 84.3 per cent (16/19) of the patients developed roentgenologic evidence of pulmonary complications, only 47.4 per cent $(9 / 19)$ had significant hypoxia $\left(\mathrm{PaO}_{2}\right.$ below $\left.70.0 \mathrm{~mm} \mathrm{Hg}\right)$. Other studies have shown postoperative pulmonary complications, as reflected by roentgenologic changes, to 


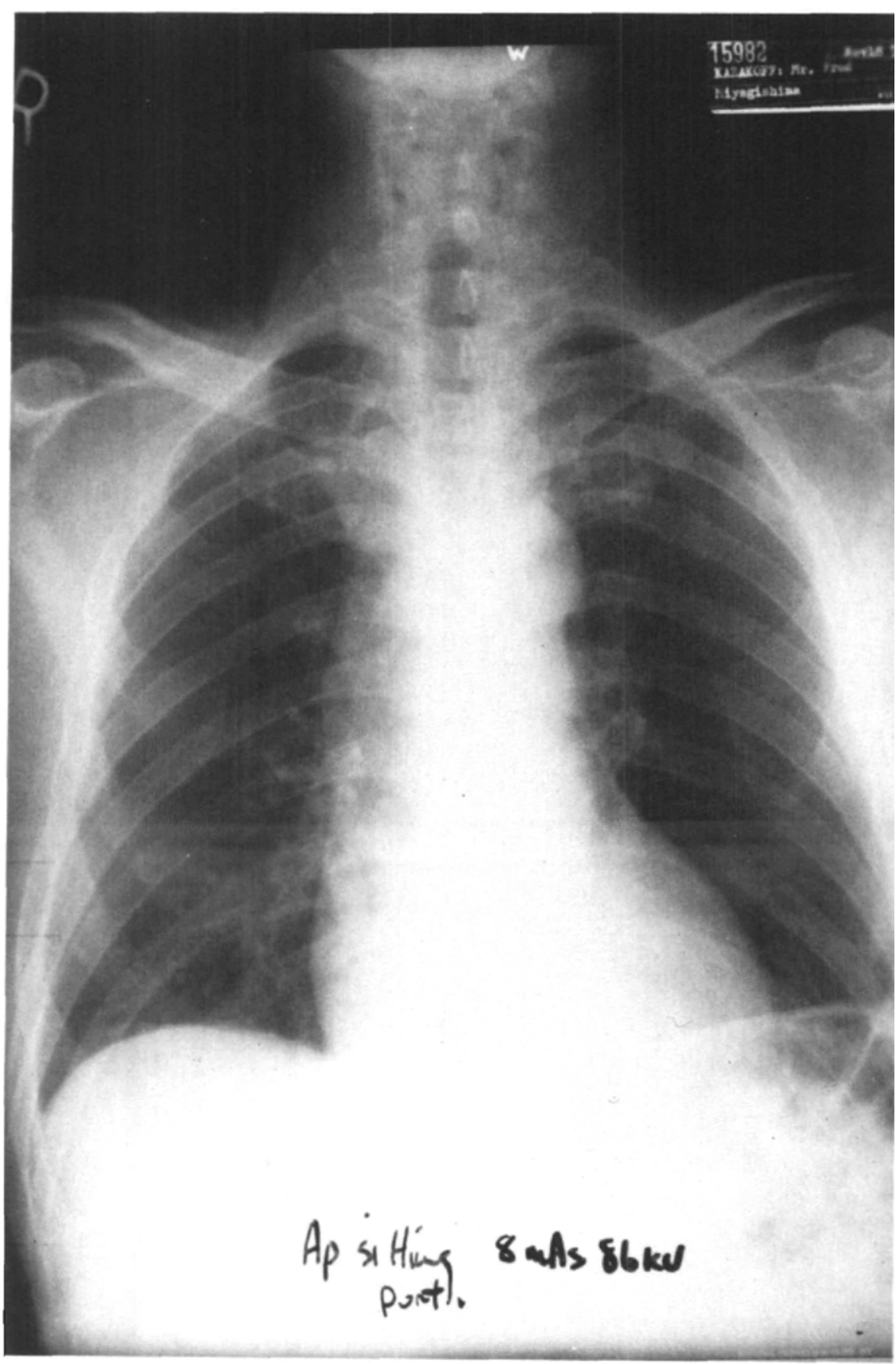

Ficure 4. Radiograph showing elevation of left diaphragm due to atelectasis of left lower lobe.

vary from 61.5 per cent to 74 per cent. ${ }^{1,4,14}$ The atelectatic changes were primarily in the left lower lobe in 68.4 per cent (13/19) of the patients, despite closed pleural spaces and particular attention to positioning of retractors to avoid contusion. Gravity, secretions, the suppression of cilia ${ }^{15}$ and phagocytosis, ${ }^{61}$ by 


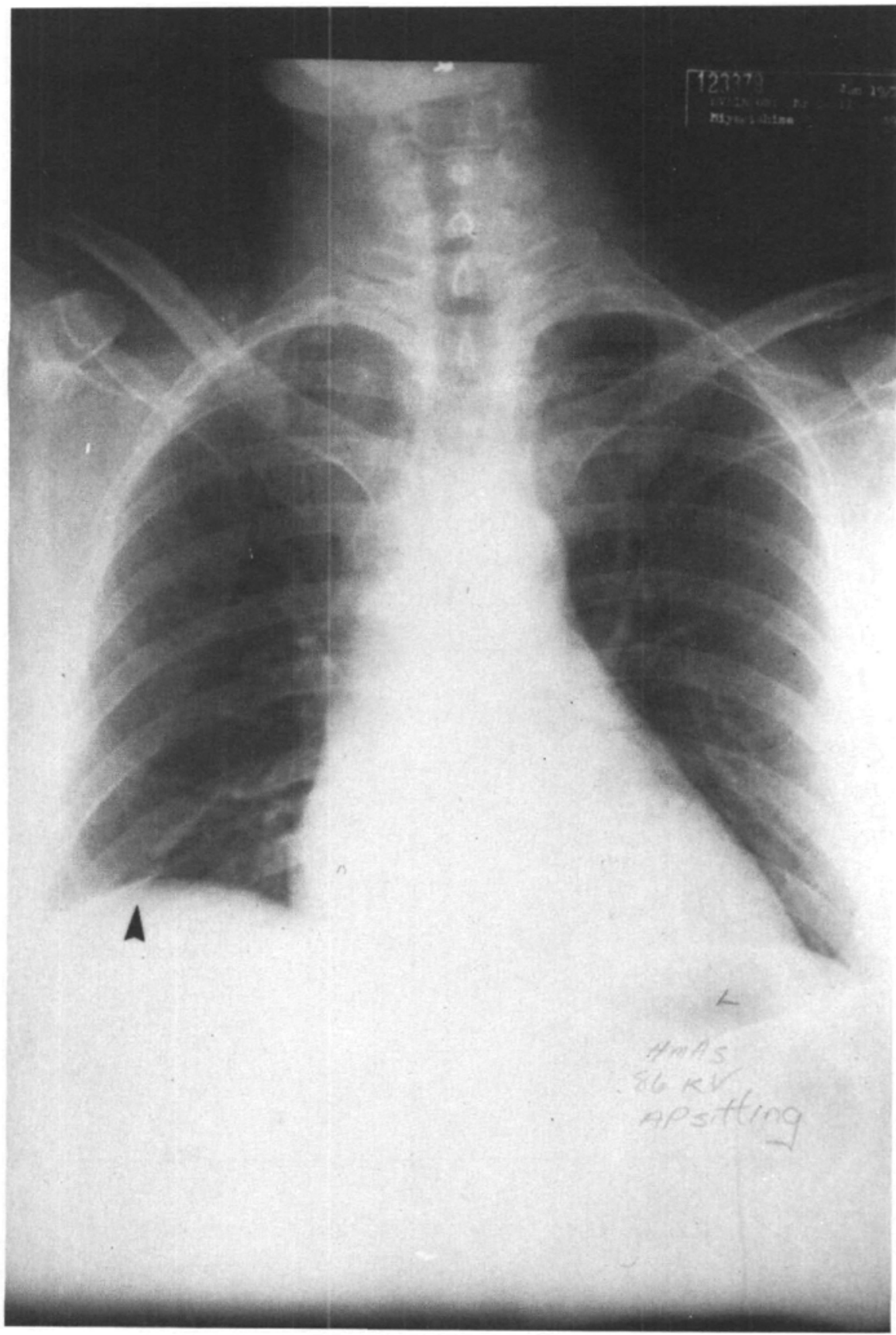

Figune 5. Radiograph showing plate atelectasis of right lower lobe and elevation of right diaphragm due to atelectasis.

general anaesthesia, bypass with suppression of surfactant, ${ }^{17}$ and the proximity of a heart which is being surgically manipulated over a lobe supplied by a bronchus which runs downward, backward and laterally ${ }^{18}$ may be the main factors causing such a common anatomical localization of the atelectasis. Any 


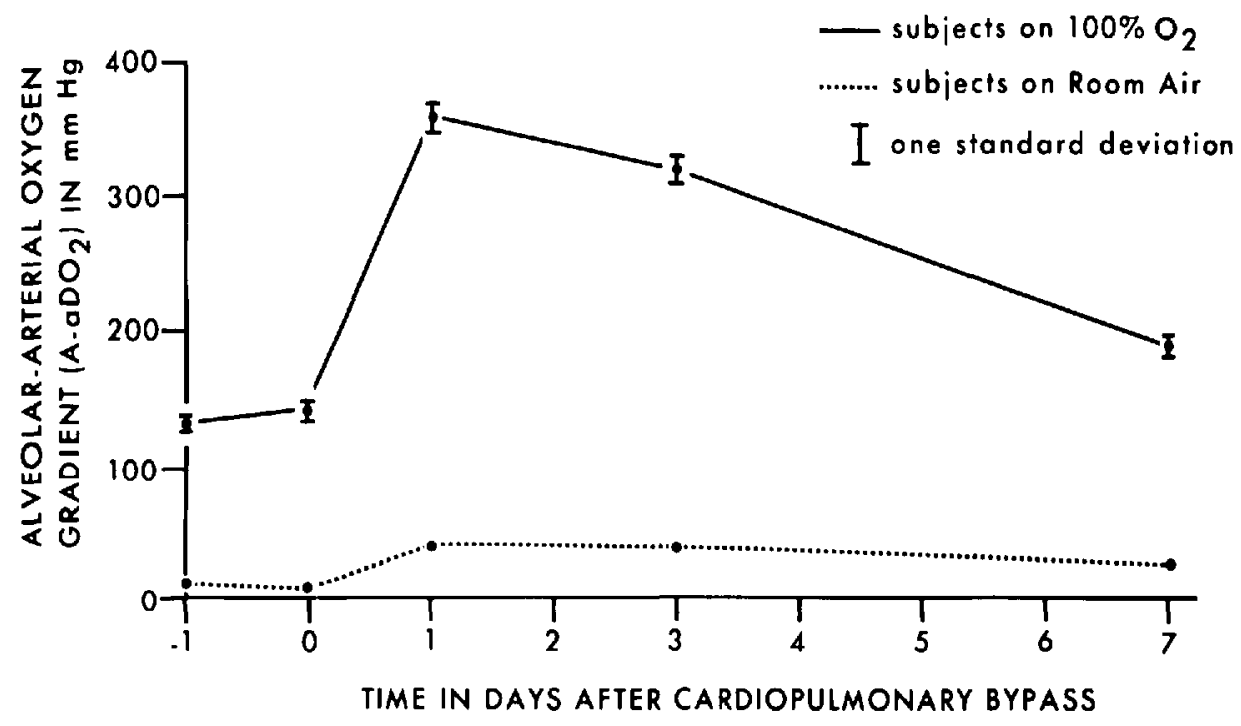

Figure 6. Variation in alveolar-arterial oxygen gradients $\left(A-\mathrm{aDO}_{2}\right)$ with time before and after cardiopulmonary bypass.

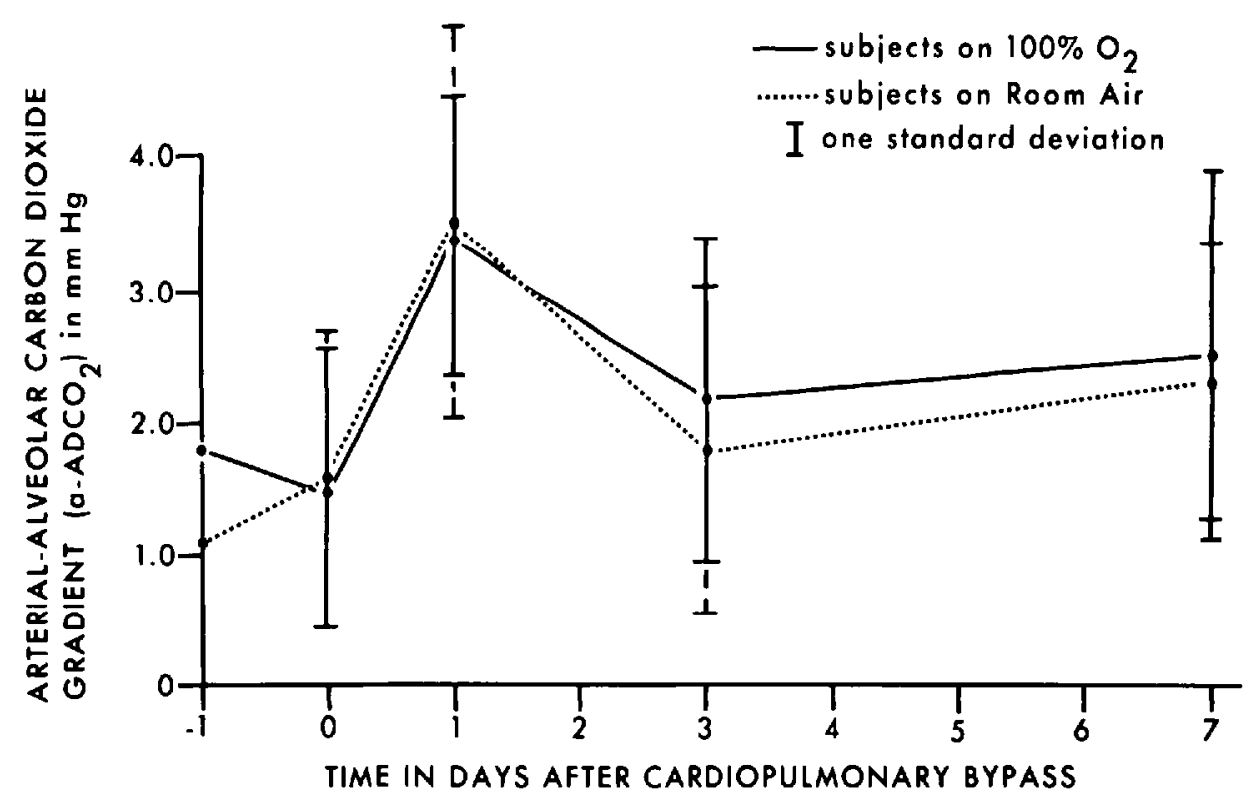

Figure 7. Variation in arterial-alveolar carbon dioxide gradients $\left(a-A D C O_{2}\right)$ with time before and after cardiopulmonary bypass.

enlargement of the heart would add further insult to the lower lobe of the left lung. Intra-operative use of adequate left ventricle venting, sighs, positive expiratory pressure plateaus ("PEPP" or "PEEP") and humidity during bypass will not stop pulmonary complications. A determined effort should be made to suction both right and left lower lobe bronchi prior to extubation. Post-operative physiotherapy with coughing, deep breathing and posturing of the patient to 


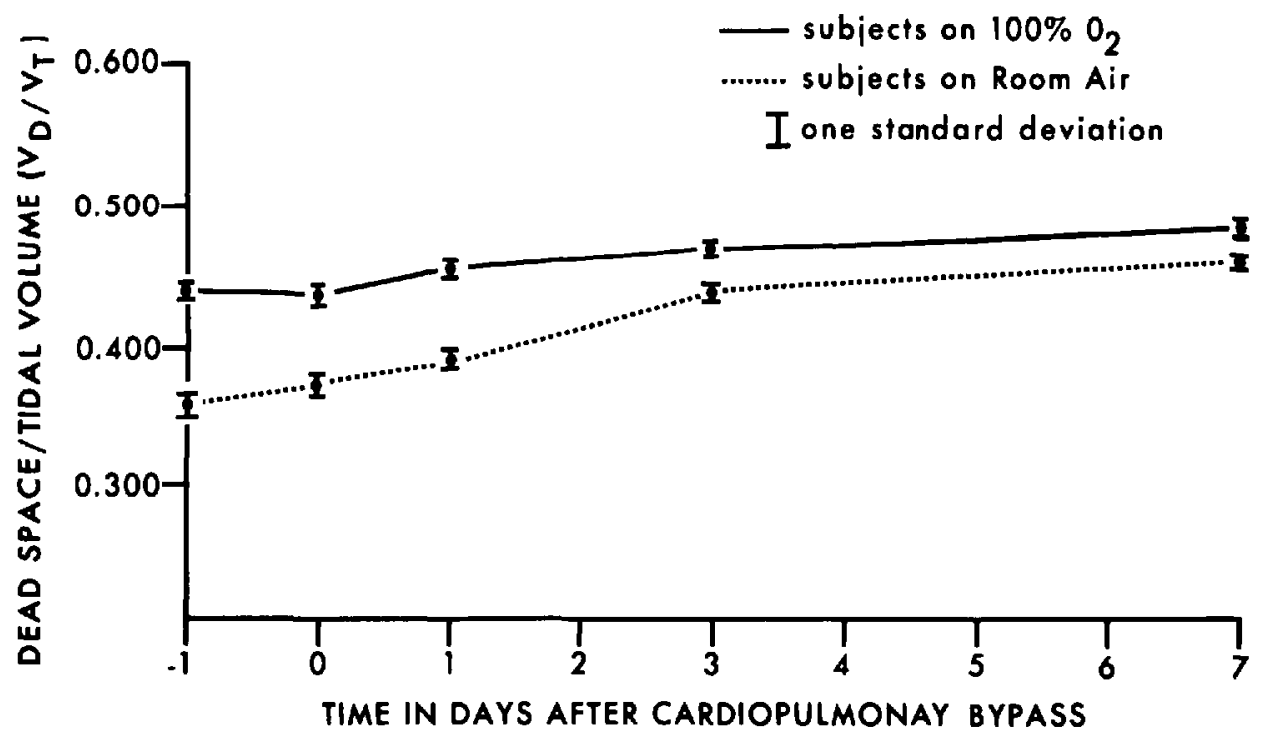

FIgURE 8. Variations in dead space-tidal volume ratio (VD/VT) with time before and after cardiopulmonary bypass.

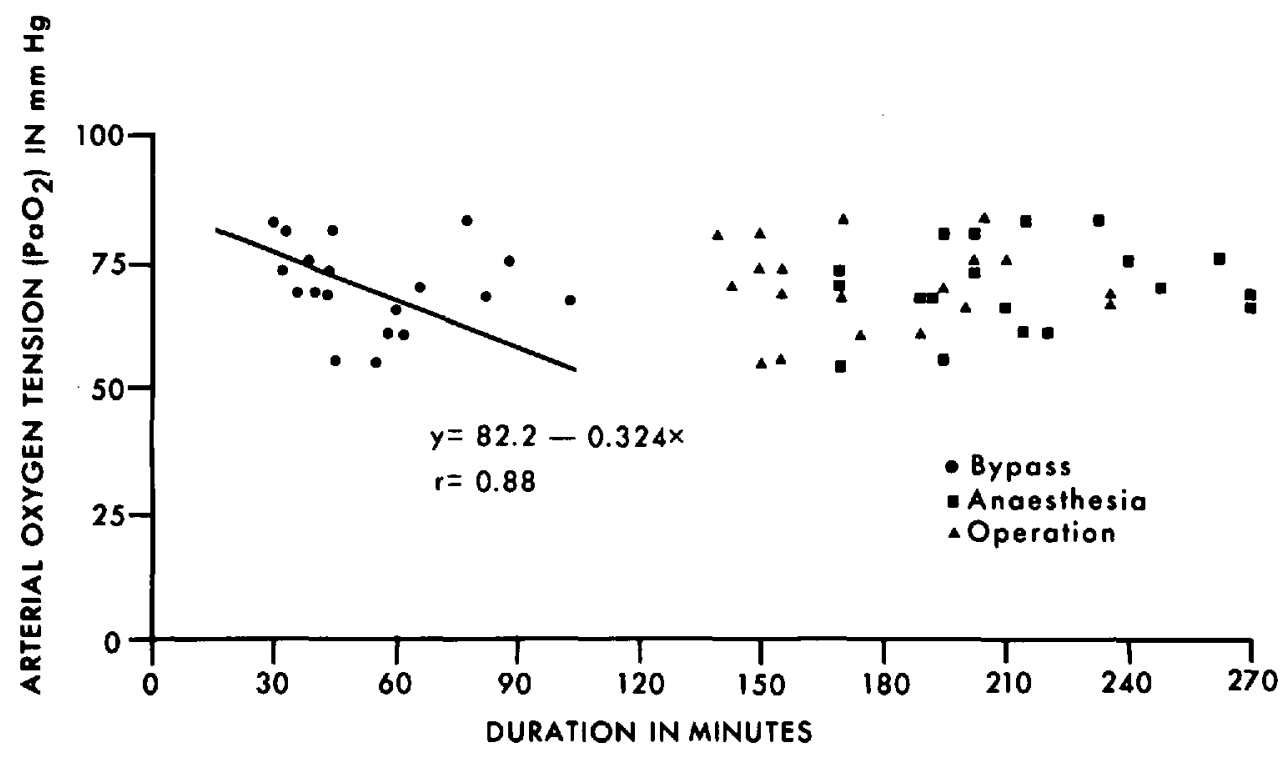

Figure 9. Variations in arterial oxygen tension $\left(\mathrm{PaO}_{2}\right) 24$ hours postoperatively (subjects on room air) with duration of bypass, operation and anaesthesia. Duration of bypass is the only significantly correlated variable.

drain especially the right and left lower lobes are essential. Close monitoring of the $\mathrm{PaO}_{2}$ is the real key to avoiding deficient oxygenation.

Further refinements for cardiopulmonary bypass should include consideration of blood and pump filters, ${ }^{19}$ continuous "PEEP," omission of blood from pump prime, use of albumin in prime, ${ }^{20}$ and partial exsanguination of blood volume prior to and re-infusion of this blood after bypass. ${ }^{21}$ 


\section{ConCLUSION}

Arterial oxygen tensions are frequently at hypoxic levels while breathing room air following cardiopulmonary bypass. Over 45 per cent of the patients in this study had a $\mathrm{PaO}_{2}$ of less than $70.0 \mathrm{~mm} \mathrm{Hg}$ and a highly significant $\mathrm{A}-\mathrm{aDO}_{2}$ gradient for one to three days after bypass. Atelectasis of the left lower lobe with a significant physiological shunt and elevation of the left diaphragm formed a typical clinical picture in more than 50 per cent of the patients studied. Attempts to limit pulmonary complications must include adequate suctioning of both lower lobes and continued post-operative physiotherapy and "stir-up" regimes. The significance of roentgenological and clinical evidence of pulmonary function in this type of patient can best be followed by $\mathrm{A}-\mathrm{aDO} \mathrm{O}_{2}$ gradients and the $\mathrm{PaO}_{2}$.

\section{SUMmary}

Pulmonary complications are extremely frequent after cardiopulmonary bypass. Hypoxic levels of arterial oxygen tension ( $\mathrm{PaO}_{.2}<70.0 \mathrm{~mm} \mathrm{Hg}$ ) occurred in more than 50 per cent of the 19 patients studied. Atelectasis or collapse of the left lower lobe is highly characteristic and was seen in more than 50 per cent of the patients studied. Pulmonary function assessment (using $\mathrm{PaO}_{2}$, a- $\mathrm{ADO}_{2}$, A-ADCO ${ }_{2}, V_{D} / V_{T}$ and $C O$ diffusing capacity $\left.D_{(0) s}\right)$ suggests that increased physiological shunting in the atelectatic or consolidated lungs is the crucial factor. This study compared pre-operative and post-operative changes in these parameters during the first week after operation. Pulmonary dysfunction was maximal 24 hours post-operatively and gradually improved during the next six days. Anatomical, anaesthetic, and manipulative factors probably predispose to the frequent involvement of the left lower lobe. The use of left ventricle venting, sighs, "PEEP" and humidity during bypass may help to minimize pulmonary complications. Suction of both lower lobe bronchi prior to extubation and postoperative physiotherapy and "stir-up" regimes are also important. The significance of roentgenological and clinical evidence of pulmonary function in this type of patient can best be followed by $\mathrm{A}-\mathrm{aDO}_{2}$ gradients and the $\mathrm{PaO}_{2}$.

\section{RÉSUMÉ}

Les complications pulmonaires sont extrèmement fréquentes après emploi de la chirurgie extracorporelle. Des niveaux hypoxiques de $\mathrm{PaO}_{2}\left[\mathrm{PaO}_{2} \leqslant 70 \mathrm{~mm} \mathrm{Hg}\right]$ furent observés chez plus de 50 pour cent des 19 patients étudiés. L’atélectasie et/ou le collapsus du lobe inférieur gauche est très caractéristique et nous l'avons retrouvé chez plus de 50 pour cent de nos patients. L'étude de la fonction respiratoire $\left[\mathrm{PaO}_{2}, \mathrm{a}-\mathrm{ADO}, \mathrm{A}-\mathrm{ADCO}, \mathrm{VD} / \mathrm{VT}\right.$, capacité de diffusion du CO DCO $\left.\mathrm{Ss}_{\mathrm{s}}\right]$ suggère que le facteur le plus important chez ces patients consiste en une augmentation du shunt physiologique dans le poumon atélectasié ou consolidé.

Notre étude a comparé les changements pré-opératoires et post-opératoires, durant la première semaine après la chirurgie. Le maximum de dysfonction pulmonaire se retrouve dans les 24 premières heures post-opératoires. Il y a récupération durant les six jours suivants. 
Des facteurs anatomiques, anesthésiques manipulatoires prédisposent probablement à l'atteinte fréquente du lobe inférieur gauche. L'usage de la décompression du ventricule gauche, des soupirs, du P.E.E.P. et de l'humidité durant la circulation extracorporelle peuvent aider à minimiser les complications pulmonaires. L'aspiration des sécrétions dans les bronches des lobes inférieurs droit et gauche avant l'extubation, la physiothérapie post-opératoire et la mobilisation active des patients sont aussi importantes.

Le gradient alvéolo-artériel et la $\mathrm{PaO}_{2}$ sont les meilleurs guides permettant d'évaluer l'importance des complications rencontrées.

\section{ACKNOWLEDGMENTS}

The financial support of the Tuberculosis and Chest Disabled Veterans' Association and the Defense Research Board of Canada is gratefully acknowledged. I am indebted to Miss M. Dodsworth and Miss M. Bedford for their technical assistance and to Dr. R.G. Pitman for his assistance in roentgenological interpretations.

\section{REFERENCES}

1. Gauert, W.B., Anderson, D.S., Reed, W.A., \& Templeton, A.W. Pulmonary complications following extracorporeal circulation. Southern Med. J. 64: 679 (1971).

2. KolfF, W.J., Effler, D.B., Graves, L.K., Hughes, C.R., \& McCormaCK, L.J. Pulmonary complications of open heart operations: their pathogenesis and avoidance. Cleveland Clin. Quart. 25: 65 (1958).

3. Hepps, S.A., Roe, B.B., Wright, R.R., \& Gardner, R.E. Amelioration of the pulmonary post-perfusion syndrome with hemodilution and low molecular weight dextran. Surgery 54: 232 (1963).

4. Phovan, J.L., Austen, W.G., \& SAnNexl, J.G. Respiratory complications after openheart surgery. J. of Thoracic \& Cardiovasc. Surg. 51: 626 (1966).

5. Filley, G.F., MacIntosh, D.J., \& Wright, G.W. Carbon monoxide uptake and pulmonary diffusing capacity in normal subjects at rest and during exercise. J. Clin. Invest. 33: 530 ( 1954 ).

6. RAHN, H. A concept of mean alveolar air and the ventilation-blood flow relationship during pulmonary gas exchange. Am. J. Physiol. 158: 21 (1949).

7. Riley, R.L., Lilienthal, J.L., Prommel, D.D., \& Franke, R.E. On the determination of the physiologically effective pressures of oxygen and carbon dioxide in alveolar air. Am. J. Physiol. 147: 191 (1946).

8. Tunnbull, K.W. \& Miyagishima, R.T. The influence of premedication with narcotics and belladonna on oxygenation in cardiac surgery patients. Canad. Anaesth. Soc. J. 19: 639 (1972).

9. Hedley-White, J., Conning, H., Laver, M.B., Austen, W.G., \& Bendixen, H.H. Pulmonary ventilation-perfusion relations after heart valve replacement or repair in man. J. Clin. Invest. 44: 406 (1965).

10. Schramel, R.J., Cameron, R., Ziskind, M., Adam. M., \& Creech, O. Studies of pulmonary diffusion after open heart surgery. J. Thor. \& Cardiovasc. Surgery 38: 281 (1959).

11. Comroe, J.H., Fonster, R.E., Dubois, A.B., Briscoe, W.A., \& Carlsen, E. The lungclinical physiology and pulmonary function tests, 2nd Ed., Chicago, Year Book Medical Publishers pp. 137-138 (1962).

12. NunN, J.F. Applied respiratory physiology, London, Butterworths, pp. 340-345 (1969).

13. Andersen, N.B. \& GHIA, J. Pulmonary function, cardiac status, and post-operative course in relation to cardiopulmonary bypass. J. Thor. \& Cardiovasc. Surgery 59: 474 (1970).

14. Templeton, A.W., Almond, C.H., Seaber, A., Simmons, C., \& MacKenzie, J. Postoperative pulmonary patterns following cardiopulmonary bypass. Am. J. Cardiol. 961: 1007 (1966). 
15. Wylie, W.D. \& ChunchILL-Davmson, H.C. A practice of anaesthesia, third ed. London, Lloyd-Luke pp. 6-8 (1972).

16. Bruce, D.L. \& Wingard, D.W. Anesthesia and the immune response. Anesthesiology 34: 271 (1971).

17. Blat, E., Hedstrand, U., Westerholme, C.J., \& Bjokk, V.O. Effect of total cardiopulmonary bypass on human lung elastic properties. Circulation 36: I-207 Suppl. 1 (1967).

18. WyLIE, W.D. \& Churchill-Davmson, H.C. A practice of anaesthesia, third ed. London, Lloyd-Luke, p. 25 (1972).

19. Conneli, R.S., Page, U.S., Bartley, T.D., Bigelow, J.C., \& Webb, M.C. The effect on pulmonary ultrastructure of dacron-wool filtration during cardiopulmonary bypass. Ann. Thor. Surg. 15: 217 (1973).

20. Wynands, J.E. Personal Communication, June, 1973.

21. ArENs, J.F. The anesthesiologist and the pump/oxygenator presented at Wilford Hall, U.S.A.F. Anesthesiology Review Course, June, 1972. 